\title{
EFFECT OF PTERYGIUM EXCISION ON PTERYGIUM INDUCED REFRACTIVE CHANGES
}

\author{
U. P. Deepankar ${ }^{1}$ Bahubali Jain ${ }^{2}$
}

${ }^{1}$ Associate Professor, Department of Ophthalmology, NSCB Medical College, Jabalpur.

${ }^{2}$ Assistant Professor, Department of Ophthalmology, NSCB Medical College, Jabalpur.

\section{ABSTRACT}

\section{BACKGROUND}

Pterygium most often refers to a benign growth of the conjunctiva. A pterygium is a triangular fibrovascular subepithelial ingrowth of degenerative bulbar conjunctival tissue over the limbus onto the cornea. It commonly grows from the nasal side of the sclera. Vision may be reduced due to astigmatism induced by the pterygium or due to direct invasion of the visual axis. This abnormality has been measured by keratometry.

\section{METHODS}

The prospective study entitled "Effect of pterygium excision on pterygium induced refractive changes" was conducted on 50 eyes on 50 patients of primary pterygium attending the Outpatient Department of Ophthalmology, NSCB Medical College and Hospital, Jabalpur from January 2015 to December 2015. The inclusion criteria were patients with primary pterygium with $\geq 2 \mathrm{D}$ WTR astigmatism as measured by manual keratometry. In the present study an attempt was made to assess the effect of pterygium excision on the induced astigmatism and the relationship between the size of pterygium and the amount of astigmatism. Preoperative and postoperative values were compared using the paired t-test.

\section{RESULTS}

The astigmatism decreased significantly following Pterygium excision. The mean preoperative refractive cylinder decreased from $3.12 \mathrm{D} \pm 2.02$ to $1.43 \mathrm{D} \pm 1.24$ postoperatively $(\mathrm{p} \leq 0.001)$ depending on grade of pterygium.

\section{CONCLUSION}

There was statistically significant correlation between grade of pterygium and induced astigmatism ( $p$-value $\leq 0.001$ ). The present study verifies the fact that amount of pterygium induced astigmatism is directly proportional to increase in the size of pterygium.

\section{KEYWORDS}

WTA, BCVA, SLE, CLAG.

HOW TO CITE THIS ARTICLE: Deepankar UP, Jain B. Effect of pterygium excision on pterygium induced refractive changes. J. Evolution Med. Dent. Sci. 2016;5(26):1376-1378, DOI: 10.14260/jemds/2016/324

\section{INTRODUCTION}

Pterygium most often refers to a benign growth of the conjunctiva. A pterygium is a triangular fibrovascular subepithelial ingrowth of degenerative bulbar conjunctival tissue over the limbus onto the cornea. ${ }^{1}$ It commonly grows from the nasal side of the sclera. It is usually present in the palpebral fissure. It is associated with and thought to be caused by exposure to ultraviolet-light (e.g. sunlight), low humidity and dust. A pterygium is histologically similar to pingueculum and shows elastotic degenerative changes in vascularized subepithelial stromal collagen.

Most patients of pterygium take treatment for cosmetic purpose. Pterygium leads to inflammation, foreign body sensation, tearing, dry and itchy eyes. Vision may be reduced due to astigmatism induced by the pterygium..$^{2}$ or due to direct invasion of the visual axis. This abnormality has been measured by keratometry. In the present study an attempt was made to assess the effect of pterygium excision on the induced astigmatism and the relationship between the size of pterygium and the amount of astigmatism.

Financial or Other, Competing Interest: None.

Submission 29-01-2016, Peer Review 05-03-2016,

Acceptance 11-03-2016, Published 31-03-2016.

Corresponding Author:

Dr. Bahubali Jain,

C 409, Vatsala Paradise, Shivnagar

Jabalpur-482002,

Madhya Pradesh.

E-mail:drbahu@gmail.com

DOI: $10.14260 /$ jemds $/ 2016 / 324$

\section{AIMS AND OBJECTIVES}

1. To evaluate prospectively the corneal astigmatism before and after pterygium surgery.

2. To evaluate the effect of pterygium excision on refractive astigmatism.

3. To study the relationship between amount of astigmatism and grade of pterygium.

\section{MATERIALS AND METHODS}

Fifty eyes of fifty patients with primary pterygium were studied before and after surgery. The inclusion criteria were patients with primary pterygium with $\geq 2$ D WTR astigmatism as measured by manual keratometry. Patients with history of trauma or surgery were excluded. It was examined to look for any evidence of congestion, xerosis or symblepharon. Deep or superficial vascularisation, conjunctivalisation and any ischaemic areas were looked for.

\section{Pterygium was Graded depending on the Extent of Corneal Involvement \\ Grade I- crossing limbus \\ Grade II- midway between limbus and pupil \\ Grade III- reaching up to pupillary margin \\ Grade IV- crossing pupillary margin}

Visual acuity was expressed as a decimal. The result was expressed as an arithmetic mean. Preoperative and postoperative values were compared using the paired t-test. Preoperative astigmatism was compared against the grade of pterygium using ANCOVA test. 


\section{OBSERVATIONS}

\begin{tabular}{|c|c|c|c|c|}
\hline \multirow{2}{*}{ Gender } & \multicolumn{2}{|c|}{ No. of Patients } & \multicolumn{2}{c|}{ No. of Eyes } \\
\cline { 2 - 5 } & No. & $\mathbf{\%}$ & No. & $\%$ \\
\hline Female & 18 & 36 & 18 & 36 \\
\hline Male & 32 & 64 & 32 & 64 \\
\hline Total & $\mathbf{5 0}$ & $\mathbf{1 0 0}$ & $\mathbf{5 0}$ & $\mathbf{1 0 0}$ \\
\hline \multicolumn{2}{|r|}{ Table 1: Gender wise Distribution of Patients } \\
\hline
\end{tabular}

The above table shows that among 50 eyes of 50 cases 32 (64\%) were male and 18 (36\%) were female.

\begin{tabular}{|c|c|c|}
\hline $\begin{array}{c}\text { Age } \\
\text { (In Years) }\end{array}$ & No. of Patients & \% of Patients \\
\hline$\leq 20$ & 03 & 06 \\
\hline$\geq 20-40$ & 24 & 48 \\
\hline$\geq 40-60$ & 18 & 36 \\
\hline$\geq 60$ & 05 & 10 \\
\hline Total & $\mathbf{5 0}$ & $\mathbf{1 0 0}$ \\
\hline \multicolumn{2}{|c|}{ Table 2: Age wise Distribution of Patients } \\
\hline
\end{tabular}

The above table shows that maximum number of cases selected consecutively were of $>20-40$ years of age; $84 \%$ of cases were $>20-60$ years of age.

\begin{tabular}{|c|c|c|}
\hline Grade of Pterygium & No. of Patients & \% of Patients \\
\hline Grade 1 & 08 & 16 \\
\hline Grade 2 & 23 & 46 \\
\hline Grade 3 & 19 & 38 \\
\hline Total & $\mathbf{5 0}$ & $\mathbf{1 0 0}$ \\
\hline \multicolumn{2}{|c|}{ Table 3: Grade wise Distribution of Patients } \\
\hline
\end{tabular}

The above table shows that maximum number of cases were in Grade II; 8 eyes (16\%) had Grade I pterygium; 19 eyes (46\%) had Grade II pterygium; 19 eyes (38\%) had Grade III pterygium.

\begin{tabular}{|c|c|}
\hline Pterygium Induced Astigmatism & Astigmatism \pm SD \\
\hline Preoperative mean & $3.24 \pm 2.01$ \\
\hline Postoperative mean & $1.47 \pm 1.20$ \\
\hline P-value & $\leq 0.001$ \\
\hline
\end{tabular}

The above table shows that mean astigmatism following pterygium surgery reduced from $3.24 \pm 2.01$ to $1.47 \pm 1.20$ (Pvalue $\leq 0.001$ ).

\begin{tabular}{|c|c|}
\hline Grade of Pterygium & Mean Astigmatism (D) \pm SD \\
\hline Grade I & $2.32 \pm 0.42$ \\
\hline Grade II & $2.84 \pm 1.26$ \\
\hline Grade III & $3.64 \pm 1.20$ \\
\hline Table 5: Pre-operative Grade wise Astigmatism \\
\hline
\end{tabular}

The above table shows that amount of astigmatism varied with the grade of pterygium. Mean astigmatism in eyes with Grade I was $2.32 \pm 0.42$ D. In eyes with Grade II pterygium astigmatism was $2.84 \pm 1.26 \mathrm{D}$ and in eyes with Grade III pterygium astigmatism was $3.64 \pm 1.20 \mathrm{D}$.

\begin{tabular}{|c|c|}
\hline Grade of Pterygium & Mean Astigmatism (D) \pm SD \\
\hline Grade I & $0.94 \pm 0.52$ \\
\hline Grade II & $1.20 \pm 0.82$ \\
\hline Grade III & $3.62 \pm 1.72$ \\
\hline \multicolumn{2}{|c|}{ Table 6: Post-op Grade wise Astigmatism } \\
\hline
\end{tabular}

The above table shows that amount of astigmatism after pterygium excision was $0.94 \pm 0.52$ in Grade I pterygium; $1.20 \pm 0.82$ in Grade II pterygium and $3.62 \pm 1.72$ in Grade III pterygium.

\begin{tabular}{|c|c|c|c|}
\hline $\begin{array}{c}\text { Grade of } \\
\text { Pterygium }\end{array}$ & $\begin{array}{c}\text { Pre-op Mean } \\
\text { Astigmatism } \\
\text { (D) } \pm \text { SD }\end{array}$ & $\begin{array}{c}\text { Post-op Mean } \\
\text { Astigmatism } \\
\text { (D) } \pm \text { SD }\end{array}$ & P-Value \\
\hline Grade I & $2.32 \pm 0.42$ & $0.94 \pm 0.52$ & 0.575 \\
\hline Grade II & $2.84 \pm 1.26$ & $1.20 \pm 0.82$ & $\leq 0.001$ \\
\hline Grade III & $3.64 \pm 1.20$ & $3.62 \pm 1.72$ & $\leq 0.001$ \\
\hline
\end{tabular}

Table 7: Comparison of Pre-op and Post-op Astigmatism

The above table shows that amount of mean astigmatism before and after pterygium excision. P-value was statistically significant in Grade II and Grade III, but not significant in Grade I.

\begin{tabular}{|c|c|c|c|}
\hline \multirow{2}{*}{ Grade of Pterygium } & \multicolumn{4}{|c|}{ Degree of Astigmatism } \\
\cline { 2 - 4 } & $\mathbf{2}$ 2-3D & $\mathbf{2 3 - 4 D}$ & $\mathbf{2 4 D}$ \\
\hline Grade I & 8 & - & - \\
\hline Grade II & 17 & 6 & - \\
\hline Grade III & 6 & 13 & - \\
\hline Total & $\mathbf{3 1}$ & $\mathbf{1 9}$ & - \\
\hline Table 8: Pre-op Grade wise Astigmatism Analysis \\
\hline
\end{tabular}

Table shows that maximum no. of cases have mean astigmatism of $\geq 2-3 \mathrm{D}$.

\begin{tabular}{|c|c|c|c|c|c|}
\hline \multirow{2}{*}{$\begin{array}{c}\text { Grade of } \\
\text { Pterygium }\end{array}$} & \multicolumn{5}{|c|}{ Degree of Astigmatism } \\
\cline { 2 - 6 } & $\mathbf{1 D}$ & $\mathbf{2 1 -}$ & $\mathbf{2}$ 2- & $\mathbf{2}$ 3- & $\geq$ \\
& 3D & 4D & 4D \\
\hline Grade I & 5 & 1 & - & - & - \\
\hline Grade II & 10 & 13 & - & - & - \\
\hline Grade III & 1 & 18 & 2 & - & - \\
\hline Total & $\mathbf{1 6}$ & $\mathbf{3 2}$ & $\mathbf{2}$ & - & - \\
\hline Table 9: Post-op Grade wise Astigmatism Analysis \\
\hline
\end{tabular}

Above table shows that in maximum number of cases amount of astigmatism following pterygium excision was $\leq 2 \mathrm{D}$.

\begin{tabular}{|c|c|}
\hline Pre-op Mean BCVA \pm SD & $0.54 \pm 0.48$ \\
\hline Post-op mean BCVA \pm SD & $0.69 \pm 0.50$ \\
\hline P-value & $\leq 0.001$ \\
\hline Table 10: BCVA Following Pterygium Excision \\
\hline
\end{tabular}

The above table shows effect of pterygium excision on BCVA, which significantly (P-value $\leq 0.001$ ) improves after pterygium excision.

\section{DISCUSSION}

Pterygium induced refractive changes can lead to visual complaints. Previous studies have shown that pterygium causes corneal distortion, which induces a significant amount of astigmatism.(3) Most of those topographic changes in the cornea have been reported to be reversed by successful pterygium surgery, although eyes with advanced pterygium may not normalize completely.(3) It has been established that pterygium surgery decreases the pterygium induced corneal astigmatism at central $3 \mathrm{~mm} \mathrm{10,} \mathrm{but} \mathrm{its} \mathrm{effect} \mathrm{on} \mathrm{whole} \mathrm{cornea}$ remains unclear.

In the present study, manual keratometer was used to study corneal astigmatism at central $3 \mathrm{~mm}$ before and after pterygium excision with CLAG. Stern GA et al. ${ }^{4}$ in 199815 have reported that the pterygium begins to induce significant degrees of astigmatism once it reaches upto $45 \%$ of the distance from the limbus to the visual axis. Astigmatism was with the rule in all patients.

The amount of astigmatism decreased significantly following pterygium excision in Grade 2 ( $\mathrm{p} \leq 0.001)$, Grade 3 $(p \leq 0.001)$ and $(p \leq 0.001)$, but in Grade 1 the amount of 
astigmatism decreased following pterygium surgery was not statistically significant ( $\mathrm{p}=0.575)$. The amount of astigmatism seen in the patients with Grade 1 pterygium ( $\geq 2 \mathrm{D}$ ) was not only due to pterygium induce refractive. This is noticed by the fact that in Grade 1 pterygium the amount of astigmatism decreased following pterygium surgery was not statistically significant $(\mathrm{p}=0.575)$.

When primary pterygium increases in size (More than Grade 1), it induces with-the-rule significant astigmatism. ${ }^{5}$ This significant astigmatism tends to increase with the increasing size of the lesion. Pterygium induced astigmatism decreased significantly by successful removal of the pterygium in Grade II and Grade III of pterygium. Our findings are in accordance with the findings of other workers Tomidokora $\mathrm{A}$ et al. in 2000.(6); Avisar R et al. in 2000.(7); Seitz B et al. in 2001.(8); S Maheshwari in 2003.(9); Bahar, Irit et al. in 2004(10); Maheshwari S in 2007.(9)

Surgical intervention resulted in an increase in the mean refractive power of cornea after one month of surgery, which indicates a steepening of the flattened cornea.

There was flattening of the cornea horizontally in the nasal quadrant, where the pterygium was located. This flattening effect dissipated after pterygium removal.(10) Our findings are in accordance with the findings of other workers Cameron ME in 1983.(3) Oldenburg et al. in 1990.(7) Pavilack MA et al. in 1993.(11) Yagmur M et al. in 2005.(12); JooYoun Oh et al. in 2010.(13)

\section{SUMMARY AND CONCLUSION}

The prospective study entitled "Effect of pterygium excision on pterygium induced refractive changes" was conducted on 50 eyes on 50 patients of primary pterygium attending the Outpatient Department of Ophthalmology, NSCB Medical College and Hospital, Jabalpur from January 2015 to December 2015. The inclusion criteria were patients with primary pterygium with $\geq 2$ D WTR astigmatism as measured by manual keratometry.

Examination includes Snellen's visual acuity, refraction and slit lamp examination and manual keratometry preoperatively and one month postoperatively. Pterygium excision with conjunctival autograft was done in all cases.

\section{The Following Observations were made}

1. In the present study, the age distribution of cases ranged between 17 and 72 years (Mean 40.52 \pm 13.06 years). Maximum number of cases belongs to $\geq 20-60$ years of age (84\%).

2. In the present study, the prevalence of pterygium was more in males (64\%) as compared to females (36\%).

3. In the present study, 8 eyes had Grade 1 pterygium, 23 eyes had Grade 2 pterygium and 19 eyes had Grade 3 pterygium.

4. The astigmatism decreased significantly following pterygium excision. The mean preoperative refractive cylinder decreased from $3.12 \mathrm{D} \pm 2.02$ to $1.43 \mathrm{D} \pm 1.24$ postoperatively $(p \leq 0.001)$. Surgical removal of pterygium caused a significant reduction in refractive astigmatism.
5. The amount of astigmatism decreased significantly following pterygium excision in Grade $2(\mathrm{p} \leq 0.001)$ and Grade 3 ( $\mathrm{p} \leq 0.001)$.

6. There was statistically significant correlation between grade of pterygium and induced astigmatism ( $p$-value $\leq 0.001$ ). The present study verifies the fact that amount of pterygium induced astigmatism is directly proportional to increase in the size of pterygium.

7. The mean horizontal refractive power of cornea increased from $41 \mathrm{D} \pm 2.00$ preoperatively to $42.53 \mathrm{D} \pm 1.86$. There was flattening of the cornea horizontally in the nasal quadrant, where the pterygium was located. This flattening effect dissipated after pterygium removal.

8. Pterygium surgery significantly improves BCVA in Grade II (from $0.58 \pm 0.44$ to $0.79 \pm p$-value $\leq 0.001$ ) and Grade III (from $0.54 \pm 0.28 \mathrm{p}$-value $\leq 0.001$ ).

\section{REFERENCES}

1. Errais K, Bouden J, Mili-Boussen I, et al. Effect of pterygium surgery on corneal topography. Eur J Ophthalmol 2008;18(2):177-81.

2. Gridley MJ, Perlman EM. A form of variable astigmatism induced by pseudopterygium. Ophthalsurg laser 1986;17(12):794-795.

3. Cinal A, Yasar T, Demirok A, et al. Effect of pterygium surgery on corneal topography. Ophthalsurg lasers 2001;32:35-40.

4. Pesudovs K, Figueiredo FC. Corneal first wavefront aberrations before and after pterygium surgery. J Refract Surg 2006;22(9):921-925.

5. Tomidokora A, Oshika T, Amano S, et al. Quantitative analysis of regular and irregular astigmatism induced by pterygium. Cornea 1999;18:412-415.

6. Tomidokoro A, Miyata K, Sakaguchi Y, et al. Effects of pterygium on corneal spherical power and astigmatism. Ophthalmology 2000;107(8):1568-71.

7. Oldenburg JB, Garbus J, McDonnell JM, et al. Conjunctival pterygia. Mechanism of corneal topographic changes. Cornea 1990;9(3):200-204.

8. Avisar R, Loya N, Yassur Y, et al. Pterygium-indiced corenal astigmatism. Isr Med Assoc J 2000;2(1):14-5.

9. Seitz B, Gutay A, Kuchle M, et al. Impact of pterygium size on coreal topography and visual acuity-a prospective clinical cross-sectional study. Klin Monbl Augenheilkd 2001;218(9):609-15.

10. Maheshwari S. Effect of pterygium excision on ptergyium induced astigmatism. ijo 2003;51(2):187-188.

11. Bahar I, Loya N, Wenberger D, et al. Effect of pterygium surgery on corneal topography: a prospective study. Cornea 2004;23(2):113-117.

12. Modhdyousu F. Role of pterygium excision in pterygium induced astigmatism. JK-Practitioner 2005;12(2):91-92.

13. Yagmur M, Ozcan AA, Sari S, et al. Visual acuity and corneal topographic changes related with pterygium surgery. J Refract surg 2005;21(2):166-70. 